\section{Cellular Physiology} and Biochemistry Published online: December 17, 2015

Accepted: November 28, 2015

This article is licensed under the Creative Commons Attribution-NonCommercial-NoDerivatives 4.0 International License (CC BY-NC-ND) (http://www.karger.com/Services/OpenAccessLicense). Usage and distribution for commercial purposes as well as any distribution of modified material requires written permission.

Original Paper

\title{
Enhanced Eryptosis Following Exposure to Lopinavir
}

\author{
Rosi Bissinger $^{\mathrm{a}}$ Sabrina Waibel ${ }^{\mathrm{a}} \quad$ Ghada Bouguerra $^{\mathrm{a}, \mathrm{b}} \quad$ Abdulla Al Mamun Bhuyan ${ }^{\mathrm{a}}$ \\ Salem Abbès ${ }^{b}$ Florian Lang ${ }^{a}$
}

aDepartment of Physiology, University of Tübingen, Tuebingen, Germany; ' ${ }^{\natural}$ Laboratoire d'Hématologie

Moléculaire et Cellulaire, Institut Pasteur de Tunis, Tunis, Tunisie

\section{Key Words}

Phosphatidylserine $\bullet$ Cell volume $\bullet$ Eryptosis $•$ Oxidative stress $\bullet$ Calcium

\begin{abstract}
Background/Aims: The protease inhibitor lopinavir, used for the treatment of HIV infections, triggers suicidal death or apoptosis of nucleated cells. Side effects of lopinavir include anemia, which could in theory result from stimulation of suicidal erythrocyte death or eryptosis, characterized by cell shrinkage and by phospholipid scrambling of the cell membrane leading to phosphatidylserine translocation to the erythrocyte surface. Stimulators of eryptosis include oxidative stress, increase of cytosolic $\mathrm{Ca}^{2+}$ activity $\left(\left[\mathrm{Ca}^{2+}\right]_{\mathrm{i}}\right)$, and ceramide. The present study explored, whether lopinavir induces eryptosis. Methods: Flow cytometry was employed to estimate phosphatidylserine exposure at the cell surface from annexin-V-binding, cell volume from forward scatter, $\left[\mathrm{Ca}^{2+}\right]$, from Fluo3-fluorescence, reactive oxygen species (ROS) abundance from 2',7'-dichlorodihydrofluorescein diacetate (DCFDA) fluorescence, reduced glutathione (GSH) from mercury orange fluorescence and ceramide abundance utilizing labelled specific antibodies. Hemolysis was estimated from haemoglobin concentration of the supernatant. Results: A 48 hours exposure of human erythrocytes to lopinavir significantly increased the percentage of annexin-V-binding cells $(\geq 10 \mu \mathrm{g} / \mathrm{ml}$ ), significantly decreased forward scatter $(\geq 15 \mu \mathrm{g} / \mathrm{ml})$, significantly increased hemolysis $(\geq 15 \mu \mathrm{g} / \mathrm{ml})$, significantly increased Fluo3fluorescence $(20 \mu \mathrm{g} / \mathrm{ml})$, and significantly increased DCFDA fluorescence $(20 \mu \mathrm{g} / \mathrm{ml})$ but did not significantly modify ceramide abundance. The effect of lopinavir on annexin-V-binding was significantly blunted, but not abolished by removal of extracellular $\mathrm{Ca}^{2+}$. Conclusion: Lopinavir treatment of erythrocytes from healthy volunteers is followed by cell shrinkage and phospholipid scrambling of the erythrocyte cell membrane, an effect in part due to stimulation of ROS formation and $\mathrm{Ca}^{2+}$ entry.




\section{Cellular Physiology Cell Physiol Biochem 2015;37:2486-2495 and Biochemistry \begin{tabular}{l|l} 
DOI: 10.1159/000438601 & (c) 2015 The Author(s). Published by S. Karger AG, Basel \\
www.karger.com/cpb
\end{tabular} \\ Bissinger et al.: Lopinavir-Induced Eryptosis}

\section{Introduction}

The protease inhibitor lopinavir is used for the treatment of HIV infections [1-13]. Side effects of lopinavir treatment include anemia [14]. Lopinavir may induce proteotoxic stress $[15,16]$, trigger oxidative stress [16], and suppress NF- $\kappa B$ activity [17]. Lopinavir may thus foster apoptosis and inhibit growth of tumor cells [15-18].

Oxidative stress may similarly trigger eryptosis, the suicidal death of erythrocytes, characterized by cell shrinkage [19] and phospholipid scrambling of the cell membrane, which is apparent from phosphatidylserine translocation to the cell surface [20]. Oxidative stress is in part effective by opening of $\mathrm{Ca}^{2+}$ permeable unselective cation channels with subsequent $\mathrm{Ca}^{2+}$ entry and increase of cytosolic $\mathrm{Ca}^{2+}$ activity $\left(\left[\mathrm{Ca}^{2+}\right]_{\mathrm{i}}\right)[20]$. Eryptosis is further triggered by ceramide [21], energy depletion [20], and caspases [20, 22, 23]. Eryptosis is stimulated by several kinases including casein kinase $1 \alpha$, Janus-activated kinase JAK3, protein kinase $C$, and p38 kinase [20]. Eryptosis is inhibited by AMP activated kinase AMPK, cGMP-dependent protein kinase, PAK2 kinase, and sorafenib/sunitinib sensitive kinases [20]. Triggers of eryptosis further include a wide variety of xenobiotics [20, 24-49]. Enhanced eryptosis is observed in several clinical conditions, such as chronic kidney disease (CKD) [29, 50-52], hemolytic-uremic syndrome [53], sepsis [54], dehydration [37], hyperphosphatemia [47], hepatic failure [55], diabetes [56], malignancy [20], malaria [20, 57-59], sickle-cell disease [20], beta-thalassemia [20], Hb-C and G6PD-deficiency [20], as well as Wilsons disease [60].

The present study explored whether lopinavir triggers eryptosis. To this end, human erythrocytes from healthy volunteers were exposed for 48 hours to lopinavir and phosphatidylserine surface abundance, cell volume, $\left[\mathrm{Ca}^{2+}\right]_{i}$, reactive oxygen species, GSH abundance and ceramide abundance determined by flow cytometry.

\section{Materials and Methods}

\section{Erythrocytes, solutions and chemicals}

Fresh Li-Heparin-anticoagulated blood samples were kindly provided by the blood bank of the University of Tübingen. The study is approved by the ethics committee of the University of Tübingen (184/2003 V). The blood was centrifuged at $120 \mathrm{x}$ g for $20 \mathrm{~min}$ at $21^{\circ} \mathrm{C}$ and the platelets and leukocytes-containing supernatant was disposed. Erythrocytes were incubated for 48 hours in vitro at a hematocrit of $0.4 \%$ in Ringer solution containing (in mM) $125 \mathrm{NaCl}, 5 \mathrm{KCl}, 1 \mathrm{MgSO}_{4}, 32 \mathrm{~N}$-2-hydroxyethylpiperazine-N-2-ethanesulfonic acid (HEPES; $\mathrm{pH}$ 7.4), 5 glucose, $1 \mathrm{CaCl}_{2}$, at $37^{\circ} \mathrm{C}$. Where indicated, erythrocytes were exposed to lopinavir (Sigma Aldrich, Hamburg, Germany) at the indicated concentrations.

\section{Annexin-V-binding and forward scatter}

After incubation under the respective experimental condition, a $150 \mu \mathrm{l}$ cell suspension was washed in Ringer solution containing $5 \mathrm{mM} \mathrm{CaCl}_{2}$ and then stained with Annexin-V-FITC (1:200 dilution; ImmunoTools, Friesoythe, Germany) in this solution at $37^{\circ} \mathrm{C}$ for $15 \mathrm{~min}$ under protection from light. The annexin V abundance at the erythrocyte surface was subsequently determined on a FACS Calibur (BD, Heidelberg, Germany). Annexin-V-binding was measured in FL-1 with an excitation wavelength of $488 \mathrm{~nm}$ and an emission wavelength of $530 \mathrm{~nm}$. A marker (M1) was placed to set an arbitrary threshold between annexin-V-binding cells and control cells. The same threshold was used for untreated and lopinavir treated erythrocytes. A dot plot of forward scatter (FSC) vs. side scatter (SSC) was set to linear scale for both parameters. The threshold of forward scatter was set at the default value of " 52 ".

\section{Hemolysis}

In order to determine hemolysis, the samples were centrifuged ( $3 \mathrm{~min}$ at $1600 \mathrm{rpm}$, room temperature) after incubation under the respective experimental conditions and the supernatants were harvested. As a measure of hemolysis, the haemoglobin $(\mathrm{Hb})$ concentration of the supernatant was determined photometrically at $405 \mathrm{~nm}$. The absorption of the supernatant of erythrocytes lysed in distilled water was defined as $100 \%$ hemolysis. Hemolysis is expressed in \% in order to allow comparison with \% annexin V binding cells. 


\section{Cellular Physiology Cell Physiol Biochem 2015;37:2486-2495

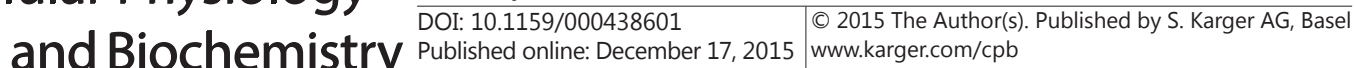 \\ Bissinger et al.: Lopinavir-Induced Eryptosis}

Intracellular $\mathrm{Ca}^{2+}$

After incubation, erythrocytes were washed in Ringer solution and then loaded with Fluo-3/AM (Biotium, Hayward, USA) in Ringer solution containing $5 \mathrm{mM} \mathrm{CaCl}_{2}$ and $5 \mu \mathrm{M}$ Fluo-3/AM. The cells were incubated at $37^{\circ} \mathrm{C}$ for $30 \mathrm{~min}$ and washed once in Ringer solution containing $5 \mathrm{mM} \mathrm{CaCl} \mathrm{Cl}_{2}$ The Fluo-3/ AM-loaded erythrocytes were resuspended in $200 \mu$ l Ringer solution. Then, $\mathrm{Ca}^{2+}$-dependent fluorescence intensity was measured in FL-1 with an excitation wavelength of $488 \mathrm{~nm}$ and an emission wavelength of $530 \mathrm{~nm}$ on a FACS Calibur.

Reactive oxygen species (ROS)

Oxidative stress was determined utilizing 2',7'-dichlorodihydrofluorescein diacetate (DCFDA). After incubation, a $150 \mu \mathrm{l}$ suspension of erythrocytes was washed in Ringer solution and then stained with DCFDA (Sigma Aldrich, Hamburg, Germany) in Ringer solution containing DCFDA at a final concentration of $10 \mu \mathrm{M}$. Erythrocytes were incubated at $37^{\circ} \mathrm{C}$ for $30 \mathrm{~min}$ in the dark and then washed two times in Ringer solution. The DCFDA-loaded erythrocytes were resuspended in $200 \mu$ l Ringer solution, and ROS-dependent fluorescence intensity was measured in FL-1 at an excitation wavelength of $488 \mathrm{~nm}$ and an emission wavelength of $530 \mathrm{~nm}$ on a FACS Calibur (BD).

\section{GSH abundance}

The content of reduced glutathione was measured using mercury orange. After incubation, erythrocytes were washed in Ringer solution and then loaded with $40 \mu \mathrm{M}$ mercury orange (Sigma-Aldrich, Hamburg, Germany) in PBS and incubated at $37^{\circ} \mathrm{C}$ for 3 mins. Afterwards, the samples were washed once and were finally resuspended in $200 \mu \mathrm{l}$ PBS. The fluorescence intensity was measured in FL-2 channel by flow cytometry at an excitation wavelength of $488 \mathrm{~nm}$ and an emission wavelength of $576 \mathrm{~nm}$.

\section{Ceramide abundance}

To determine the ceramide abundance at the erythrocyte surface, a monoclonal antibody was used. After incubation, cells were stained for $1 \mathrm{~h}$ at $37^{\circ} \mathrm{C}$ with $1 \mu \mathrm{g} / \mathrm{ml}$ anti-ceramide antibody (clone MID 15B4; Alexis, Grünberg, Germany) in phosphate-buffered saline (PBS) containing $0.1 \%$ bovine serum albumin (BSA) at a dilution of 1:10. After two washing steps with PBS-BSA, cells were stained for 30 min with polyclonal fluorescein-isothiocyanate (FITC)-conjugated goat anti-mouse IgG and IgM specific antibody (BD Pharmingen, Hamburg, Germany) diluted 1:50 in PBS-BSA. Unbound secondary antibody was removed by repeated washing with PBS-BSA. Samples were then analyzed by flow cytometric analysis in FL-1 at an excitation wavelength of $488 \mathrm{~nm}$ and an emission wavelength of $530 \mathrm{~nm}$.

\section{Statistics}

Data are expressed as arithmetic means \pm SEM. As indicated in the figure legends, statistical analysis was made using ANOVA with Tukey's test as post-test and $t$ test as appropriate. $\mathrm{n}$ denotes the number of different erythrocyte specimens studied. Since different erythrocyte specimens used in distinct experiments are differently susceptible to triggers of eryptosis, the same erythrocyte specimens have been used for control and experimental conditions.

\section{Results}

The present study tested whether lopinavir stimulates suicidal erythrocyte death or eryptosis. The two hallmarks of eryptosis are cell shrinkage and phospholipid scrambling of the cell membrane with phosphatidylserine translocation to the cell surface. Annexin-Vbinding was determined by flow cytometry as a measure of phosphatidylserine exposure at the erythrocyte surface. The measurements were made following incubation for 48 hours in Ringer solution without or with lopinavir $(5-20 \mu \mathrm{g} / \mathrm{ml})$. As illustrated in Fig. 1, a 48 hours exposure to lopinavir was followed by an increase of phosphatidylserine exposing erythrocytes, an effect reaching statistical significance at $10 \mu \mathrm{g} / \mathrm{ml}$ lopinavir.

In order to identify shrunken erythrocytes, erythrocyte volume was estimated from forward scatter, which was determined utilizing flow cytometry. Again, the measurements 


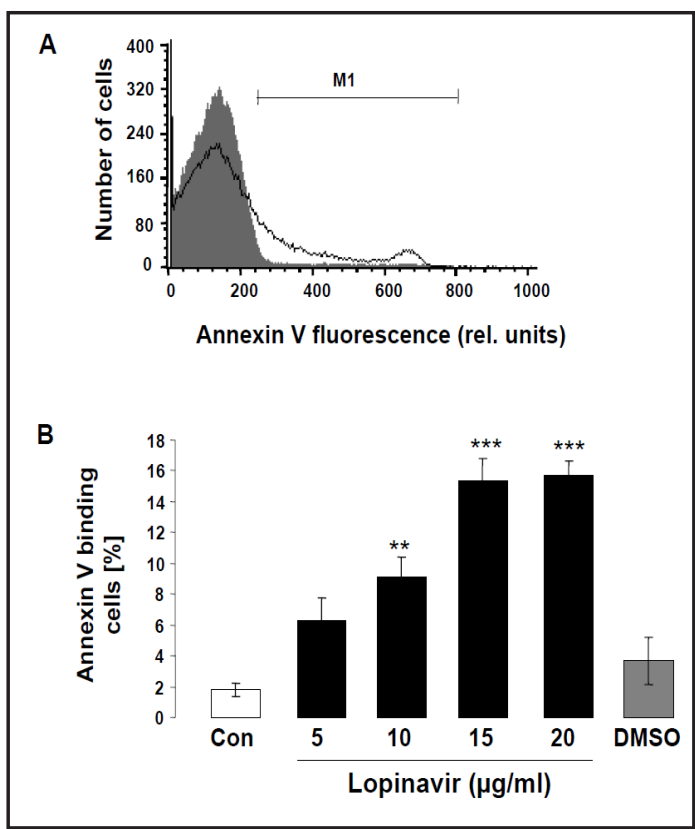

Fig. 1. Effect of lopinavir on phosphatidylserine exposure. A. Original histogram of annexin-V-binding of erythrocytes following exposure for 48 hours to Ringer solution without (grey area) and with (black line) presence of $20 \mu \mathrm{g} / \mathrm{ml}$ lopinavir. B. Arithmetic means \pm SEM $(n=12)$ of erythrocyte annexin-Vbinding (black bars) following incubation for 48 hours to Ringer solution without (white bar) or with (black bars) presence of lopinavir (5 - $20 \mu \mathrm{g} / \mathrm{ml}$ ). For comparison, the effect of the solvent DMSO (grey bar $)$ is provided. ${ }^{* *}(p<0.01),{ }^{* * *}(p<0.001)$ indicate significant difference from the absence of lopinavir (ANOVA).
A

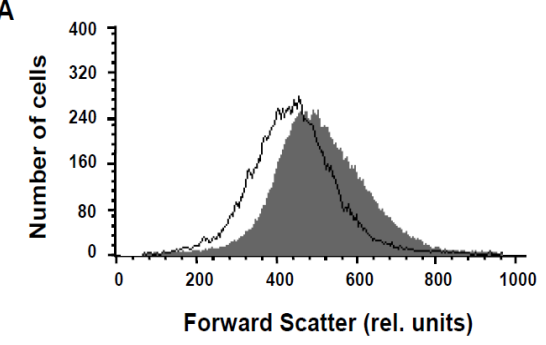

B

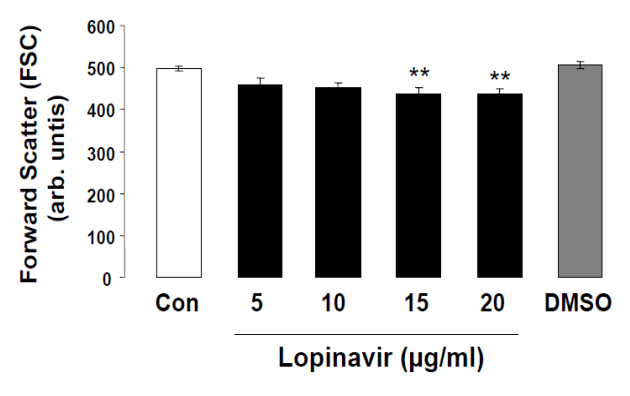

Fig. 2. Effect of lopinavir on erythrocyte forward scatter. A. Original histogram of forward scatter of erythrocytes following exposure for 48 hours to Ringer solution without (grey area) and with (black line) presence of $20 \mu \mathrm{g} / \mathrm{ml}$ lopinavir. B. Arithmetic means \pm SEM $(n=12)$ of the erythrocyte forward scatter (FSC) following incubation for 48 hours to Ringer solution without (white bar) or with (black bars) presence of lopinavir (5 - $20 \mu \mathrm{g} / \mathrm{ml}$ ). For comparison, the effect of the solvent DMSO (grey bar) is provided. ${ }^{* *}(p<0.01)$ indicates significant difference from the absence of lopinavir (ANOVA).

were made following a 48 hours incubation in Ringer solution without or with lopinavir (5-20 $\mu \mathrm{g} / \mathrm{ml})$. As apparent from Fig. 2, lopinavir treatment was followed by a decrease of erythrocyte forward scatter, an effect reaching statistical significance at $15 \mu \mathrm{g} / \mathrm{ml}$ lopinavir concentration.

In order to estimate the effect of lopinavir on hemolysis, the haemoglobin concentration in the supernatant was determined. As a result, following a 48 hours incubation the percentage hemolysed erythrocytes inceased from $1.9 \pm 0.2 \%(\mathrm{n}=4)$ in the absence of lopinavir to 3.6 $\pm 0.4 \%(5 \mu \mathrm{g} / \mathrm{ml}), 7.9 \pm 1.8 \%(10 \mu \mathrm{g} / \mathrm{ml}), 15.7 \pm 2.2 \%(15 \mu \mathrm{g} / \mathrm{ml})$ and $28.8 \pm 6.7 \%(20 \mu \mathrm{g} /$ $\mathrm{ml})$ in the presence of lopinavir $(\mathrm{n}=4$ each). The effect reached statistical significance at 15 $\mu \mathrm{g} / \mathrm{ml}$ lopinavir concentration.

Cytosolic $\mathrm{Ca}^{2+}$ activity $\left(\left[\mathrm{Ca}^{2+}\right]_{\mathrm{i}}\right)$ was estimated utilizing Fluo3 fluorescence. As illustrated in Fig. 3, a 48 hours exposure to lopinavir was followed by an increase of the Fluo3 fluorescence, an effect reaching statistical significance at $20 \mu \mathrm{g} / \mathrm{ml}$ lopinavir concentration.

In order to test whether the effect of lopinavir on phosphatidylserine translocation required entry of extracellular $\mathrm{Ca}^{2+}$, erythrocytes were incubated for 48 hours in the absence or presence of $20 \mu \mathrm{g} / \mathrm{ml}$ lopinavir in the presence or nominal absence of extracellular $\mathrm{Ca}^{2+}$. As apparent from Fig. 4, removal of extracellular $\mathrm{Ca}^{2+}$ significantly blunted the effect of lopinavir on annexin-V-binding. However, even in the absence of extracellular $\mathrm{Ca}^{2+}$, lopinavir significantly increased the percentage of annexin-V-binding erythrocytes. Thus, lopinavir 
Fig. 3. Effect of lopinavir on erythrocyte $\mathrm{Ca}^{2+}$ activity. A. Original histogram of Fluo3 fluorescence in erythrocytes following exposure for 48 hours to Ringer solution without (grey area) and with (black line) presence of $20 \mu \mathrm{g} / \mathrm{ml}$ lopinavir. B. Arithmetic means \pm SEM $(n=12)$ of the Fluo3 fluorescence (arbitrary units) in erythrocytes exposed for 48 hours to Ringer solution without (white bar) or with (black bars) presence of lopinavir $(5-20 \mu \mathrm{g} / \mathrm{ml})$. For comparison, the effect of the solvent DMSO (grey bar) is provided. $*(p<0.05)$ indicates significant difference from the absence of lopinavir (ANOVA).
A

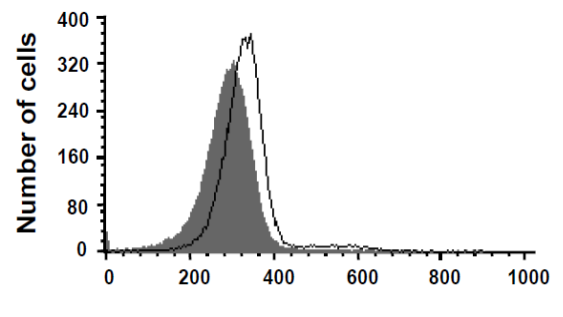

Fluo3 fluorescence (rel. units)

B

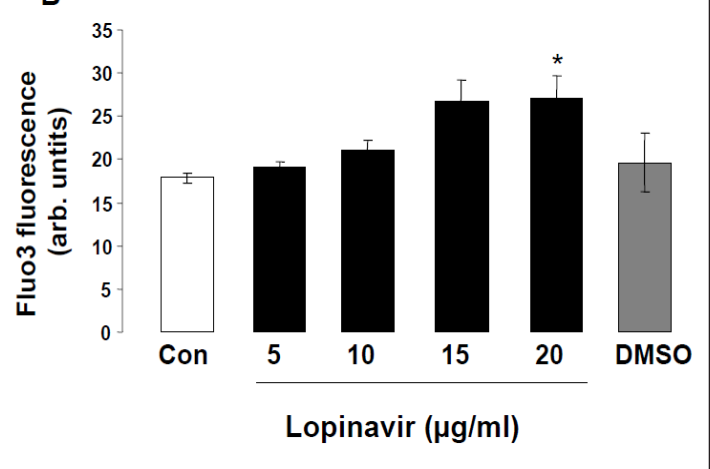

Fig. 4. $\mathrm{Ca}^{2+}$ sensitivity of lopinavir -induced phosphatidylserine exposure. A,B. Original histogram of annexin-V-binding of erythrocytes following exposure for 48 hours to Ringer solution without (grey area) and with (black line) presence of $20 \mu \mathrm{g} / \mathrm{ml}$ lopinavir in the presence (A) and absence (B) of extracellular $\mathrm{Ca}^{2+}$. C. Arithmetic means \pm SEM ( $\mathrm{n}$ = 11) of annexin-V-binding of erythrocytes after a 48 hours treatment with Ringer solution without (white bars) or with (black bars) presence of $20 \mu \mathrm{g} / \mathrm{ml}$ lopinavir $(20 \mu \mathrm{g} /$ $\mathrm{ml}$ ) in the presence (left bars,
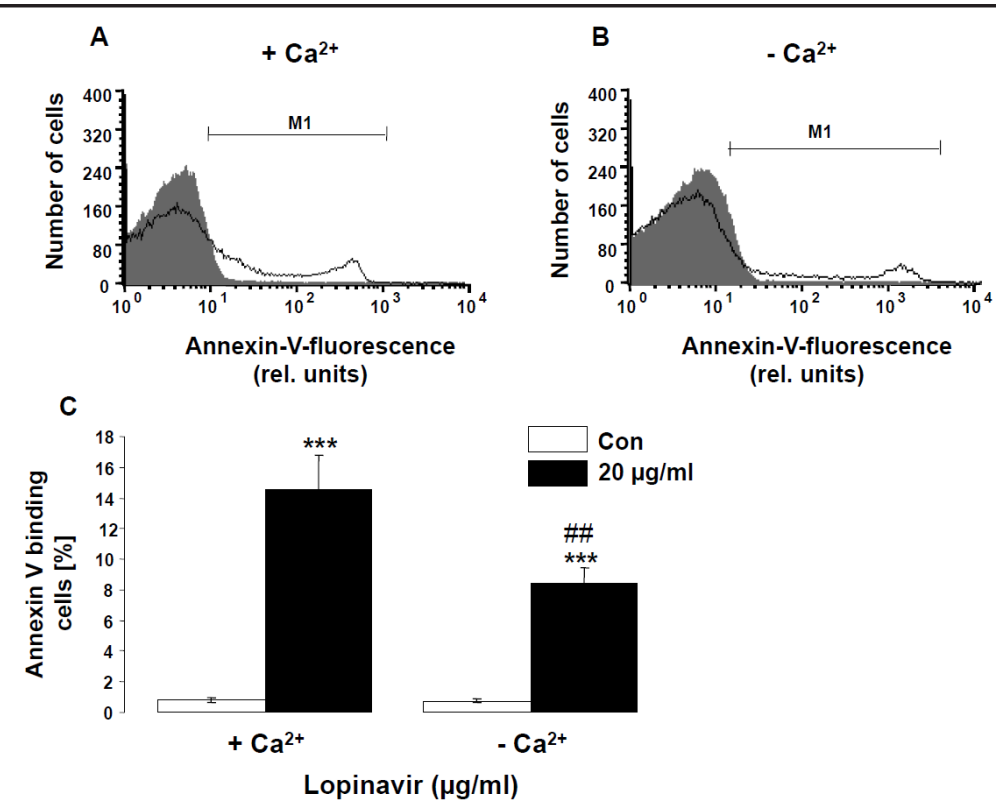

$\left.+\mathrm{Ca}^{2+}\right)$ and absence (right bars, $\left.-\mathrm{Ca}^{2+}\right)$ of $\mathrm{Ca}^{2+} . * * *(p<0.001)$ indicates significant difference from the absence of lopinavir, \#\# $(p<0.01)$ indicates significant difference from the presence of $\mathrm{Ca}^{2+}($ ANOVA).

triggered erythrocyte cell membrane scrambling in part but not exclusively by stimulating entry of extracellular $\mathrm{Ca}^{2+}$.

Stimulators of $\mathrm{Ca}^{2+}$ entry and eryptosis include oxidative stress. DCFDA $\left(2^{\prime}, 7^{\prime}\right.$-dichlorodihydrofluorescein diacetate) was thus employed to quantify reactive oxygen species (ROS). As illustrated in Fig. 5, a 48 hours exposure to lopinavir (20 $\mu \mathrm{g} / \mathrm{ml})$ was followed by a significant increase of DCFDA fluorescence. Accordingly, lopinavir induced oxidative stress. 
A

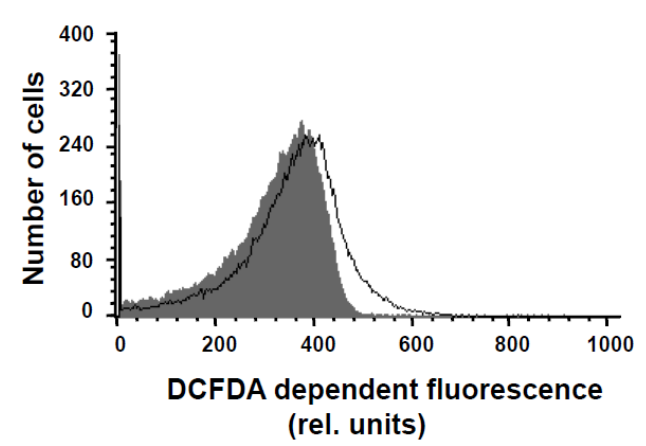

B

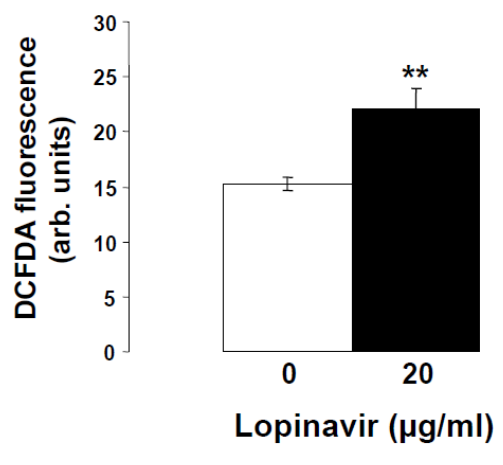

Fig. 5. Effect of lopinavir on erythrocyte ROS formation. A. Original histogram of DCFDA fluorescence in erythrocytes following exposure for 48 hours to Ringer solution without (grey area) and with (black line) presence of $20 \mu \mathrm{g} / \mathrm{ml}$ lopinavir. B. Arithmetic means \pm SEM $(\mathrm{n}=8)$ of the DCFDA fluorescence (arbitrary units) in erythrocytes exposed for 48 hours to Ringer solution without (white bar) or with (black bar) presence of $20 \mu \mathrm{g} / \mathrm{ml}$ lopinavir. ${ }^{* *}(p<0.01)$ indicates significant difference from the absence of lopinavir (paired $t$ test).

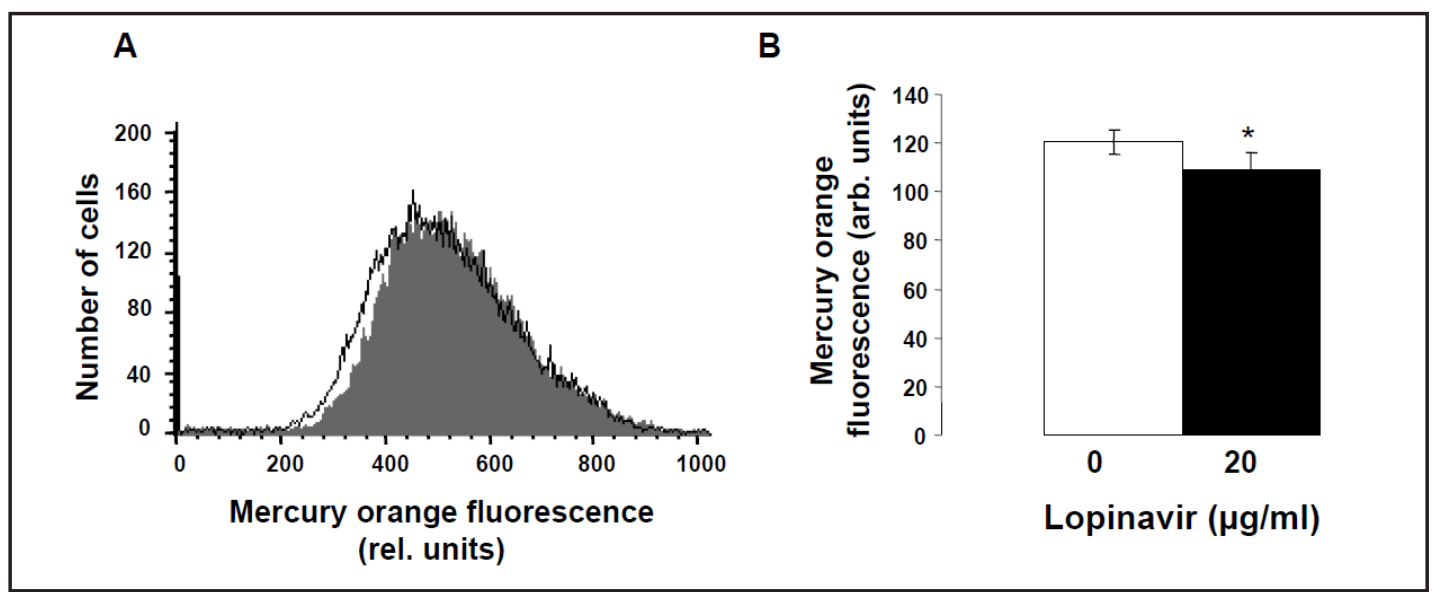

Fig. 6. Effect of lopinavir on erythrocyte GSH level. A.Original histogram of mercury orange fluorescence of erythrocytes following exposure for 48 hours to Ringer solution without (grey area) and with (black line) presence of $20 \mu \mathrm{g} / \mathrm{ml}$ lopinavir. B. Arithmetic means \pm SEM ( $\mathrm{n}=16)$ of mercury orange fluorescence (arbitrary units) in erythrocytes exposed for 48 hours to Ringer solution without (white bar) or with (black bar) presence of $20 \mu \mathrm{g} / \mathrm{ml}$ lopinavir. $*(p<0.05)$ indicates significant difference from the absence of lopinavir (paired $t$ test).

The enhanced oxidative stress could have resulted from decreased GSH levels leading to an impaired anti-oxidative stress defense. Thus, mercury orange staining was employed to quantify GSH abundance. As illustrated in Fig. 6, the mercury orange-dependent fluorescence was significantly lower after exposure to $20 \mu \mathrm{g} / \mathrm{ml}$ lopinavir for 48 hours compared to exposure to Ringer solution.

Additional experiments addressed the impact of lopinavir on ceramide abundance at the erythrocyte surface. The ceramide abundance was quantified utilizing specific antibodies. As a result, following a 48 hours incubation, the ceramide abundance was similar following incubation with $20 \mu \mathrm{g} / \mathrm{ml}$ lopinavir (15.6 \pm 0.5 a.u., $\mathrm{n}=11)$ and in the absence of lopinavir (15.7 \pm 0.4 a.u., $\mathrm{n}=11)$. 


\section{Cellular Physiology Cell Physiol Biochem 2015;37:2486-2495

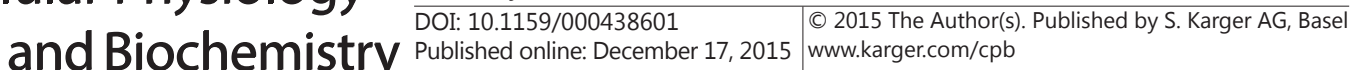 \\ Bissinger et al.: Lopinavir-Induced Eryptosis}

\section{Discussion}

The present observations unravel a novel effect of lopinavir, i.e. the stimulation of eryptosis, the suicidal erythrocyte death. Exposure of human erythrocytes drawn from healthy individuals to lopinavir is followed by cell shrinkage and phospholipid scrambling of the cell membrane with phosphatidylserine translocation to the erythrocyte surface. The effect of lopinavir on eryptosis was accompanied by enhanced hemolysis. The concentrations required for the effect are well in the range of plasma concentrations determined in patients under lopinavir treatment [61]. The observed eryptosis and hemolysis may thus well explain the anemia following lopinavir treatment [14].

The effect of lopinavir on cell membrane scrambling was obviously in large part due to increase of cytosolic $\mathrm{Ca}^{2+}$ activity $\left(\left[\mathrm{Ca}^{2+}\right]_{\mathrm{j}}\right)$ resulting from $\mathrm{Ca}^{2+}$ entry from the extracellular space. Accordingly, removal of extracellular $\mathrm{Ca}^{2+}$ significantly blunted the lopinavir-induced cell membrane scrambling. $\mathrm{Ca}^{2+}$ entered presumably through $\mathrm{Ca}^{2+}$ permeable cation channels, which are known to be activated by oxidative stress [20]. As apparent from the increase of DCFDA fluorescence, lopinavir treatment did increase the abundance of reactive oxygen species. The increase in oxidative stress was paralleled by a decreased GSH abundance.

The increase of $\left[\mathrm{Ca}^{2+}\right]_{i}$ presumably further accounts for the observed lopinavir-induced erythrocyte shrinkage, as an increase of $\left[\mathrm{Ca}^{2+}\right]_{\mathrm{i}}$ leads to activation of $\mathrm{Ca}^{2+}$ sensitive $\mathrm{K}^{+}$channels with subsequent cell shrinkage due to $\mathrm{K}^{+}$exit, cell membrane hyperpolarization, $\mathrm{Cl}^{-}$exit and thus cellular loss of $\mathrm{KCl}$ with water [19].

The stimulation of eryptosis by lopinavir may lead to anemia, as long as the formation of new erythrocytes cannot match the loss of eryptotic erythrocytes [20]. Moreover, phosphatidylserine exposing erythrocytes adhere to the vascular wall [62], stimulate blood clotting, and trigger thrombosis [63-65]. The stimulation of eryptosis by lopinavir may thus compromize microcirculation [21, 63, 66-69].

In conclusion, lopinavir triggers eryptosis with cell shrinkage and cell membrane scrambling, an effect paralleled by and in part due to induction of oxidative stress and increase of cytosolic $\mathrm{Ca}^{2+}$ activity.

\section{Acknowledgements}

The authors acknowledge the meticulous preparation of the manuscript by Tanja Loch. The study was supported by the Deutsche Forschungsgemeinschaft.

\section{Disclosure Statement}

The authors of this manuscript state that they do not have any conflict of interests and nothing to disclose.

\section{References}

1 Barragan P, Podzamczer D: Lopinavir/ritonavir: a protease inhibitor for HIV-1 treatment. Expert Opin Pharmacother 2008;9:2363-2375.

2 Caswell RJ, Phillips D, Chaponda M, Khoo SH, Taylor GP, Ghanem M, Poulton M, Welch J, Gibbons S, Jackson V, Lambert JS: Utility of therapeutic drug monitoring in the management of HIV-infected pregnant women in receipt of lopinavir. Int J STD AIDS 2011;22:11-14.

3 Chandwani A, Shuter J: Lopinavir/ritonavir in the treatment of HIV-1 infection: a review. Ther Clin Risk Manag 2008;4:1023-1033.

4 Chetchotisakd P: The CASTLE study: atazanavir/r versus lopinavir/ $\mathrm{r}$ in antiretroviral-naive patients. Expert Rev Anti Infect Ther 2009; 7:801-805.

5 Croxtall JD, Perry CM: Lopinavir/Ritonavir: a review of its use in the management of HIV-1 infection. Drugs 2010;70:1885-1915. 


\section{Cellular Physiology Cell Physiol Biochem 2015;37:2486-2495 \begin{tabular}{l|l|l}
\hline DOI: 10.1159/000438601 & $\begin{array}{l}\text { C) } 2015 \text { The Author(s). Published by S. Karger AG, Basel } \\
\text { www.karger.com/cpb }\end{array}$ \\
\hline
\end{tabular} \\ Bissinger et al.: Lopinavir-Induced Eryptosis}

6 Marchetti G, Merlini E, Sinigaglia E, Iannotti N, Bai F, Savoldi A, Tincati C, Carpani G, Bini T, Arminio Monforte A: Immune reconstitution in HIV+ subjects on lopinavir/ritonavir-based HAART according to the severity of pre-therapy CD4+. Curr HIV Res 2012;10:597-605.

7 Martinez BL, Riordan FA: Novel strategies in the use of lopinavir/ritonavir for the treatment of HIV infection in children. HIV AIDS (Auckl) 2010;2:59-67.

8 Moultrie H, McIlleron H, Sawry S, Kellermann T, Wiesner L, Kindra G, Gous H, Van Rie A: Pharmacokinetics and safety of rifabutin in young HIV-infected children receiving rifabutin and lopinavir/ritonavir. J Antimicrob Chemother 2015;70:543-549.

9 Murphy RA, Marconi VC, Gandhi RT, Kuritzkes DR, Sunpath H: Coadministration of lopinavir/ritonavir and rifampicin in HIV and tuberculosis co-infected adults in South Africa. PLoS One 2012;7:e44793.

10 Pasley MV, Martinez M, Hermes A, d'Amico R, Nilius A: Safety and efficacy of lopinavir/ritonavir during pregnancy: a systematic review. AIDS Rev 2013;15:38-48.

11 Perry M, Taylor GP, Sabin CA, Conway K, Flanagan S, Dwyer E, Stevenson J, Mulka L, McKendry A, Williams E, Barbour A, Dermont S, Roedling S, Shah R, Anderson J, Rodgers M, Wood C, Sarner L, Hay P, Hawkins D, deRuiter A: Lopinavir and atazanavir in pregnancy: comparable infant outcomes, virological efficacies and preterm delivery rates. HIV Med 2015;10.1111/hiv.12277

12 Pitrak DL, Estes R, Novak RM, Linnares-Diaz M, Tschampa JM: Beneficial effects of a switch to a Lopinavir/ ritonavir-containing regimen for patients with partial or no immune reconstitution with highly active antiretroviral therapy despite complete viral suppression. AIDS Res Hum Retroviruses 2011;27:659-667.

13 Torres B, Rallon NI, Lonca M, Diaz A, Alos L, Martinez E, Cruceta A, Arnaiz JA, Leal L, Lucero C, Leon A, Sanchez M, Negredo E, Clotet B, Gatell JM, Benito JM, Garcia F: Immunological function restoration with lopinavir/ritonavir versus efavirenz containing regimens in HIV-infected patients: a randomized clinical trial. AIDS Res Hum Retroviruses 2014;30:425-433.

14 Reekie J, Reiss P, Ledergerber B, Sedlacek D, Parczewski M, Gatell J, Katlama C, Fatkenheuer G, Lundgren JD, Mocroft A, Euro Ssg: A comparison of the long-term durability of nevirapine, efavirenz and lopinavir in routine clinical practice in Europe: a EuroSIDA study. HIV Med 2011;12:259-268.

15 Kraus M, Muller-Ide H, Ruckrich T, Bader J, Overkleeft H, Driessen C: Ritonavir, nelfinavir, saquinavir and lopinavir induce proteotoxic stress in acute myeloid leukemia cells and sensitize them for proteasome inhibitor treatment at low micromolar drug concentrations. Leuk Res 2014;38:383-392.

16 Taura M, Kariya R, Kudo E, Goto H, Iwawaki T, Amano M, Suico MA, Kai H, Mitsuya H, Okada S: Comparative analysis of ER stress response into HIV protease inhibitors: lopinavir but not darunavir induces potent ER stress response via ROS/JNK pathway. Free Radic Biol Med 2013;65:778-788.

17 Kariya R, Taura M, Suzu S, Kai H, Katano H, Okada S: HIV protease inhibitor Lopinavir induces apoptosis of primary effusion lymphoma cells via suppression of NF-kappaB pathway. Cancer Lett 2014;342:52-59.

18 Johnson MD, O'Connell M, Pilcher W: Lopinavir inhibits meningioma cell proliferation by Akt independent mechanism. J Neurooncol 2011;101:441-448.

19 Lang PA, Kaiser S, Myssina S, Wieder T, Lang F, Huber SM: Role of Ca2+-activated K+ channels in human erythrocyte apoptosis. Am J Physiol Cell Physiol 2003;285:C1553-C1560.

20 Lang F, Qadri SM: Mechanisms and significance of eryptosis, the suicidal death of erythrocytes. Blood Purif 2012;33:125-130.

21 Abed M, Towhid ST, Mia S, Pakladok T, Alesutan I, Borst O, Gawaz M, Gulbins E, Lang F: Sphingomyelinaseinduced adhesion of eryptotic erythrocytes to endothelial cells. Am J Physiol Cell Physiol 2012;303:C991999.

22 Lau IP, Chen H, Wang J, Ong HC, Leung KC, Ho HP, Kong SK: In vitro effect of CTAB- and PEG-coated gold nanorods on the induction of eryptosis/erythroptosis in human erythrocytes. Nanotoxicology 2012;6:847856.

23 Maellaro E, Leoncini S, Moretti D, Del Bello B, Tanganelli I, De Felice C, Ciccoli L: Erythrocyte caspase-3 activation and oxidative imbalance in erythrocytes and in plasma of type 2 diabetic patients. Acta Diabetol 2013;50:489-495.

24 Jilani K, Lang F: Carmustine-induced phosphatidylserine translocation in the erythrocyte membrane. Toxins (Basel) 2013;5:703-716.

25 Vota DM, Maltaneri RE, Wenker SD, Nesse AB, Vittori DC: Differential erythropoietin action upon cells induced to eryptosis by different agents. Cell Biochem Biophys 2013;65:145-157. 


\section{Cellular Physiology Cell Physiol Biochem 2015;37:2486-2495 \begin{tabular}{l|l|l} 
and Biochemistry 10.1159/000438601 & $\begin{array}{l}\text { C) } 2015 \text { The Author(s). Published by S. Karger AG, Basel } \\
\text { www.karger.com/cpb }\end{array}$ \\
\hline Published online: December 17, 2015
\end{tabular} \\ Bissinger et al.: Lopinavir-Induced Eryptosis}

26 Zappulla D: Environmental stress, erythrocyte dysfunctions, inflammation, and the metabolic syndrome: adaptations to CO2 increases? J Cardiometab Syndr 2008;3:30-34.

27 Lupescu A, Jilani K, Zbidah M, Lang F: Patulin-induced suicidal erythrocyte death. Cell Physiol Biochem 2013;32:291-299.

28 Abed M, Zoubi KA, Theurer M, Lang F: Effect of dermaseptin on erythrocytes. Basic Clin Pharmacol Toxicol 2013;113:347-352.

29 Ahmed MS, Langer H, Abed M, Voelkl J, Lang F: The uremic toxin acrolein promotes suicidal erythrocyte death. Kidney Blood Press Res 2013;37:158-167.

30 Ghashghaeinia M, Cluitmans JC, Toulany M, Saki M, Koberle M, Lang E, Dreischer P, Biedermann T, Duszenko M, Lang F, Bosman GJ, Wieder T: Age Sensitivity of NFkappaB Abundance and Programmed Cell Death in Erythrocytes Induced by NFkappaB Inhibitors. Cell Physiol Biochem 2013;32:801-813.

31 Alzoubi K, Honisch S, Abed M, Lang F: Triggering of Suicidal Erythrocyte Death by Penta-O-galloyl-beta-dglucose. Toxins (Basel) 2014;6:54-65.

32 Jilani K, Enkel S, Bissinger R, Almilaji A, Abed M, Lang F: Fluoxetine induced suicidal erythrocyte death. Toxins (Basel) 2013;5:1230-1243.

33 Lupescu A, Bissinger R, Jilani K, Lang F: Triggering of suicidal erythrocyte death by celecoxib. Toxins (Basel) 2013;5:1543-1554.

34 Arnold M, Lang E, Modicano P, Bissinger R, Faggio C, Abed M, Lang F: Effect of nitazoxanide on erythrocytes. Basic Clin Pharmacol Toxicol 2014;114:421-426.

35 Oswald G, Alzoubi K, Abed M, Lang F: Stimulation of suicidal erythrocyte death by ribavirin. Basic Clin Pharmacol Toxicol 2014;114:311-317.

36 Lupescu A, Bissinger R, Herrmann T, Oswald G, Jilani K, Lang F: Induction of suicidal erythrocyte death by novobiocin. Cell Physiol Biochem 2014;33:670-680.

37 Abed M, Feger M, Alzoubi K, Pakladok T, Frauenfeld L, Geiger C, Towhid ST, Lang F: Sensitization of erythrocytes to suicidal erythrocyte death following water deprivation. Kidney Blood Press Res 2013;37:567-578.

38 Alzoubi K, Calabròa S, Bissinger R, Abed M, Faggio C, Lang F: Stimulation of Suicidal Erythrocyte Death by Artesunate. Cell Physiol Biochem 2014;34:2232-2244.

39 Arnold M, Bissinger R, Lang F: Mitoxantrone-induced suicidal erythrocyte death. Cell Physiol Biochem 2014;34:1756-1767.

40 Bissinger R, Fischer S, Jilani K, Lang F: Stimulation of Erythrocyte Death by Phloretin. Cell Physiol Biochem 2014;34:2256-2265.

41 Bissinger R, Lupescu A, Zelenak C, Jilani K, Lang F: Stimulation of eryptosis by cryptotanshinone. Cell Physiol Biochem 2014;34:432-442.

42 Bissinger R, Modicano P, Frauenfeld L, Lang E, Jacobi J, Faggio C, Lang F: Estramustine-induced suicidal erythrocyte death. Cell Physiol Biochem 2013;32:1426-1436.

43 Jacobi J, Lang E, Bissinger R, Frauenfeld L, Modicano P, Faggio C, Abed M, Lang F: Stimulation of erythrocyte cell membrane scrambling by mitotane. Cell Physiol Biochem 2014;33:1516-1526.

44 Lupescu A, Bissinger R, Warsi J, Jilani K, Lang F: Stimulation of erythrocyte cell membrane scrambling by gedunin. Cell Physiol Biochem 2014;33:1838-1848.

45 Malik A, Bissinger R, Calabro S, Faggio C, Jilani K, Lang F: Aristolochic Acid Induced Suicidal Erythrocyte Death. Kidney Blood Press Res 2014;39:408-419.

46 Tesoriere L, Attanzio A, Allegra M, Cilla A, Gentile C, Livrea MA: Oxysterol mixture in hypercholesterolemiarelevant proportion causes oxidative stress-dependent eryptosis. Cell Physiol Biochem 2014;34:10751089.

47 Voelkl J, Alzoubi K, Mamar AK, Ahmed MS, Abed M, Lang F: Stimulation of suicidal erythrocyte death by increased extracellular phosphate concentrations. Kidney Blood Press Res 2013;38:42-51.

48 Zhang R, Xiang Y, Ran Q, Deng X, Xiao Y, Xiang L, Li Z: Involvement of calcium, reactive oxygen species, and ATP in hexavalent chromium-induced damage in red blood cells. Cell Physiol Biochem 2014;34:1780-1791.

49 Pagano M, Faggio C: The use of erythrocyte fragility to assess xenobiotic cytotoxicity. Cell Biochem Funct 2015;33:351-355.

50 Abed M, Artunc F, Alzoubi K, Honisch S, Baumann D, Foller M, Lang F: Suicidal erythrocyte death in endstage renal disease. J Mol Med (Berl) 2014;92:871-879. 


\section{Cellular Physiology Cell Physiol Biochem 2015;37:2486-2495 \begin{tabular}{l|l|l} 
and Biochemistry 10.1159/000438601 & $\begin{array}{l}\text { C) } 2015 \text { The Author(s). Published by S. Karger AG, Basel } \\
\text { www.karger.com/cpb }\end{array}$ \\
\hline Published online: December 17, 2015
\end{tabular} \\ Bissinger et al.: Lopinavir-Induced Eryptosis}

51 Polak-Jonkisz D, Purzyc L: Ca(2+) influx versus efflux during eryptosis in uremic erythrocytes. Blood Purif 2012;34:209-210; author reply 210.

52 Calderon-Salinas JV, Munoz-Reyes EG, Guerrero-Romero JF, Rodriguez-Moran M, Bracho-Riquelme RL, Carrera-Gracia MA, Quintanar-Escorza MA: Eryptosis and oxidative damage in type 2 diabetic mellitus patients with chronic kidney disease. Mol Cell Biochem 2011;357:171-179.

53 Lang PA, Beringer O, Nicolay JP, Amon O, Kempe DS, Hermle T, Attanasio P, Akel A, Schafer R, Friedrich B, Risler T, Baur M, Olbricht CJ, Zimmerhackl LB, Zipfel PF, Wieder T, Lang F: Suicidal death of erythrocytes in recurrent hemolytic uremic syndrome. J Mol Med (Berl) 2006;84:378-388.

54 Kempe DS, Akel A, Lang PA, Hermle T, Biswas R, Muresanu J, Friedrich B, Dreischer P, Wolz C, Schumacher U, Peschel A, Gotz F, Doring G, Wieder T, Gulbins E, Lang F: Suicidal erythrocyte death in sepsis. J Mol Med (Berl) 2007;85:273-281.

55 Lang E, Gatidis S, Freise NF, Bock H, Kubitz R, Lauermann C, Orth HM, Klindt C, Schuier M, Keitel V, Reich M, Liu G, Schmidt S, Xu HC, Qadri SM, Herebian D, Pandyra AA, Mayatepek E, Gulbins E, Lang F, Haussinger D, Lang KS, Foller M, Lang PA: Conjugated bilirubin triggers anemia by inducing erythrocyte death. Hepatology 2015;61:275-284.

56 Nicolay JP, Schneider J, Niemoeller OM, Artunc F, Portero-Otin M, Haik G, Jr., Thornalley PJ, Schleicher E, Wieder T, Lang F: Stimulation of suicidal erythrocyte death by methylglyoxal. Cell Physiol Biochem 2006;18:223-232.

57 Ayi K, Giribaldi G, Skorokhod A, Schwarzer E, Prendergast PT, Arese P: 16alpha-bromoepiandrosterone, an antimalarial analogue of the hormone dehydroepiandrosterone, enhances phagocytosis of ring stage parasitized erythrocytes: a novel mechanism for antimalarial activity. Antimicrob Agents Chemother 2002;46:3180-3184.

58 Ayi K, Turrini F, Piga A, Arese P: Enhanced phagocytosis of ring-parasitized mutant erythrocytes: a common mechanism that may explain protection against falciparum malaria in sickle trait and beta-thalassemia trait. Blood 2004;104:3364-3371.

59 Cappadoro M, Giribaldi G, O'Brien E, Turrini F, Mannu F, Ulliers D, Simula G, Luzzatto L, Arese P: Early phagocytosis of glucose-6-phosphate dehydrogenase (G6PD)-deficient erythrocytes parasitized by Plasmodium falciparum may explain malaria protection in G6PD deficiency. Blood 1998;92:2527-2534.

60 Lang PA, Schenck M, Nicolay JP, Becker JU, Kempe DS, Lupescu A, Koka S, Eisele K, Klarl BA, Rubben H, Schmid KW, Mann K, Hildenbrand S, Hefter H, Huber SM, Wieder T, Erhardt A, Haussinger D, Gulbins E, Lang F: Liver cell death and anemia in Wilson disease involve acid sphingomyelinase and ceramide. Nat Med 2007;13:164-170.

61 Moholisa RR, Schomaker M, Kuhn L, Meredith S, Wiesner L, Coovadia A, Strehlau R, Martens L, Abrams EJ, Maartens G, McIlleron H: Plasma lopinavir concentrations predict virological failure in a cohort of South African children initiating a protease-inhibitor-based regimen. Antivir Ther 2014;19:399-406.

62 Borst O, Abed M, Alesutan I, Towhid ST, Qadri SM, Foller M, Gawaz M, Lang F: Dynamic adhesion of eryptotic erythrocytes to endothelial cells via CXCL16/SR-PSOX. Am J Physiol Cell Physiol 2012;302:C644-C651.

63 Andrews DA, Low PS: Role of red blood cells in thrombosis. Curr Opin Hematol 1999;6:76-82.

64 Chung SM, Bae ON, Lim KM, Noh JY, Lee MY, Jung YS, Chung JH: Lysophosphatidic acid induces thrombogenic activity through phosphatidylserine exposure and procoagulant microvesicle generation in human erythrocytes. Arterioscler Thromb Vasc Biol 2007;27:414-421.

65 Zwaal RF, Comfurius P, Bevers EM: Surface exposure of phosphatidylserine in pathological cells. Cell Mol Life Sci 2005;62:971-988.

66 Closse C, Dachary-Prigent J, Boisseau MR: Phosphatidylserine-related adhesion of human erythrocytes to vascular endothelium. Br J Haematol 1999;107:300-302.

67 Gallagher PG, Chang SH, Rettig MP, Neely JE, Hillery CA, Smith BD, Low PS: Altered erythrocyte endothelial adherence and membrane phospholipid asymmetry in hereditary hydrocytosis. Blood 2003;101:46254627.

68 Pandolfi A, Di Pietro N, Sirolli V, Giardinelli A, Di Silvestre S, Amoroso L, Di Tomo P, Capani F, Consoli A, Bonomini M: Mechanisms of uremic erythrocyte-induced adhesion of human monocytes to cultured endothelial cells. J Cell Physiol 2007;213:699-709.

69 Wood BL, Gibson DF, Tait JF: Increased erythrocyte phosphatidylserine exposure in sickle cell disease: flowcytometric measurement and clinical associations. Blood 1996;88:1873-1880. 